\title{
MULTIPLE RELIGIOUS BELONGING AND THE NEW WAY OF DOING THEOLOGY
}

\author{
Alexander Hendra Dwi Asmara
}

\begin{abstract}
:
Realitas tentang identitas keagamaan ganda telah membawa teologi Kristiani menuju pada arah yang baru, yakni teologi lintas-iman, teologi yang bertumpu pada konteks daripada teks, pengalaman daripada pemikiran yang abstrak. Identitas keagamaan ganda telah menjadi bahan kajian teologis. Namun, kajian teologis kerap kali berhenti pada abstraksi yang jauh dari kenyataan. Maka, analis atas pengalaman nyata dari pelaku keagamaan ganda akan memberi nuansa baru pada kajian teologis tersebut. Tulisan ini membahas kompleksitas istilah keagamaan ganda dan analisis teologis atas fenomena tersebut. Analisis atas pengalaman konkret dari individu dan kelompok yang memiliki identitas keagamaan ganda pada bagian akhir dari tulisan ini menjadi bentuk terapan teologis.
\end{abstract}

\section{Key Words:}

Multiple religious, methodology, context, doing theology.

\section{INTRODUCTION}

The history of theology shows the shift of its focus and discussion as a response to new questions in each different time. In this recent time, the phenomenon of multiple religious belonging offers a new context of theology, a "sign of the time" as it were, where the Church is striving to see "what the Spirit is saying to her" (Apoc. 2:7) through this situation. Multiple religious belonging shows a new theological concern where plurality of religions deeply influences Christianity:

Theology is moving toward a pluriconfessional theology that we could also call inter-religious or multi-religious, or (always paying attention to the nuances of the word) trans-religious. There are those who also speak of a post-religional theology (religious but beyond the religions, on a level that is deeper), secular in that sense, and with a planetary awareness in this new knowledge society that in some way is being brought about little by little all across the planet, even in those places where they think it isn't evident. $^{1}$

This phenomenon raises a question for theology: Why could there not be an inter-religious, multi-faith theology? The "world theology," a theology that is multi-religious, global, planetary which is more than "interreligious," something also more than a theology pointed toward a preoccupation for "interreligious dialogue will be the concern for theology."2

Jacques Dupuis and Aloysius Pieris are among the theologians who have responded to this issue. Their theological project aims to build an open theology, a theology that gives emphasis on religious pluralism, including on the issue of multiple religious belonging. Arguing from the inclusivist point of view, Dupuis' Trinitarian Christology offers a doctrinal approach for multiple religious belonging; meanwhile, Pieris offers a symbiosis approach and a strong critique of inclusivism. 
Thus, Pieris develops an inductive theology, arising out of and responding to everyday encounter among religions. He argues that religion would not need to be brought into dialogue; they are dialogical and identities would not need to be multiplied; they are multiple. ${ }^{3}$ These theologians show different approach: Dupuis represents the religious elite, for he approaches the issue as an intellectual problem; while Pieris is recognized as the practical theologian on account of his solidarity with the poor. $^{4}$

Multiple religious belonging is not simply a theoretical object which manifests in a doctrinal or intellectual level, but it is a lived experience; an expression of ordinary people. Van Braght points out that the phenomenon of multiple religious belonging in Asia is their everyday cross-religious participation. ${ }^{5}$ Thus, their experiences of multiple religious belonging involve more with the practices, symbols, meditations, prayers, chants rather than the theological and doctrinal issue. ${ }^{6}$ The theological issue is not absent from their experience, but it is usually a secondary concern. Their experiences certainly give another perspective beyond the level of religious elites in the doctrinal reflections of theologians since there are real and fluid practices of the "masses" than can shed light as well.

The following paper would like to discuss multiple religious belonging through theological lens, especially in Dupuis and Pieris' theological works. However, since multiple religious belonging is not simply an abstract reality but a living experience, this paper would like to offers a theological analysis to the real issues, the "grassroots" experiences of ordinary people who deeply practice multiple religious belonging so that based on that analyses, an actual and concrete reflection can be formulated.

\section{MULTIPLE RELIGIOUS BELONG- ING: THE CATEGORY AND ITS COMPLEXITY}

The core idea of "multiple religious belonging” primarily refers to people of faith who engage in the communities and practices of more than one religious tradition. ${ }^{7}$ However, since the phenomenon of multiple religious belonging is experienced differently and the field research is so widely dispersed, there are various interpretations on this new phenomenon. It is regarded as a term for "New Age" syncretism and "dual identity" (self-identification) with no reference to institutional belonging, ${ }^{8}$ a hybrid religiosity ${ }^{9}$, a process of building Christian identity ${ }^{10}$, a process that presupposes interreligious dialogue, ${ }^{11}$ a form of resistance to the authoritative figure and others. Thus, to find a precise definition which represents various interpretations seems overconfidence.

To solve this difficulty, I will refers to Catherine Cornille's approach. Cornille uses a range of degrees or scale where each may be seen as bipolar, having two extremes (a "non-ideal soft weak implicit" and an "ideal strong hard explicit" form of multiple religious belonging), between which a range of options exists. It varies from a lighthearted flirting with different religions to a serious commitment to more than one tradition. ${ }^{12}$ At the soft pole of the scale is New Age spirituality, in which the absolute truth claims of all institutionalized forms of religion is rejected; thus it can be understood as the absence of religious belonging. In this soft scale of multiple religious belonging, there are no conscious identification with a religious community and recognition by that community as a member.

At the hard pole of scale, one finds a strong sense of multiple religious belonging, namely having two equally strong religious identities simultaneously. In this point, we can cite the famous selfdescribing words of RaimundoPanikkar: "I 'left' as a Christian, 'found myself' a Hindu and I 'return' as a Buddhist, without having ceased to be Christian."13 It is an ideal sense, as Catherine Cornille points out, which demands a total commitment and willingness to adopt and live the beliefs, moral rules, rituals, and monastic practices of religious traditions other than his or her own religion. ${ }^{14}$ In other words, it is more than a "subjective sense of sympathy or endorsement of a selective number of beliefs and practices. It involves the recognition of one's religious identity by the tradition itself and the disposition to submit to the condition for membership as delineated by that tradition." ${ }^{15}$ Religious belonging is about the complete surrender of one's own will and judgment to a truth and power that lies beyond or beneath one's own rational and personal judgment.

In my opinion, Robert Schreiter also offers a significant interpretation on multiple religious belonging as he is able to bring the issue in relation with Christian identity. For him, this phenomenon is a part in the process of forming the Christian identity. ${ }^{16}$ The formation of Christian identity involves three types: formation through resistance, through hybridity, (including syncretism and multiple religious belonging) and from hierarchy. ${ }^{17}$ The second set of identity called hybridi- 
ties is formed from an erasure of a boundary between two religious entities and a redrawing of a new boundary which involves two other processes: syncretistic process and multiple religious belonging. ${ }^{18}$ Syncretism is connected to the issue of purity and fidelity where a syncretistic community has become impure and apostate due to their falling away from the true faith or true religion. ${ }^{19}$

Meanwhile, multiple religious belonging touches the issue of identity in a pluralistic context, which can be divided into three types:

(1) those where Christianity and the other religion are perceived as two distinct religious tradition with both being practiced side by side; people follow both sets of rituals and see no contradiction in doing so; (2) those where Christianity is primary, with some selection of elements from second religious tradition, which is nonetheless practiced separately from Christianity; (3) those where it is necessary to practice other religious tradition in order to practice Christianity deeply ("Can one really be Burmese or Thai without being Buddhist?”).20

Schreiter argues that the practice of multiple religious belonging shows the mutual relationship where religions mutually enrich in order to deepen the faith. Paul F. Knitter in his book Without Buddha I Could Not Be a Christian shares the same idea that how his understanding of particular ideas, doctrines and practices of Christianity were challenged, enhanced and given fresh meaning after learning about and experiencing analogous ideas, doctrines and practices of Buddhism. ${ }^{21}$ The Christian identity deepen through the encounter with other religious traditions.

In Schreiter's perspective, multiple religious belonging does not primarily mean that people "belong" to multiple religions in the standard sense of adding or simply combining several affiliations, but it means that people of faith construct their sense of religious belonging using beliefs, expressions and practices of various religious traditions, without even bothering whether they would like to be recognized as "belonging" to those traditions by the traditions themselves. ${ }^{22}$ In other words, multiple religious belonging begins by choosing or rooting in a single tradition, while seeking its constant transformation by the inspiration of others. ${ }^{23}$
Peter C. Phanviews that multiple religious belonging shows the absence of one exclusive affiliation to a certain or single religion, but this absence does not necessarily indicate an absence of religious commitment. In fact, multiple religious commitment is necessary as the way of deepening and enriching one's religion or mutual complementarity among religions. To belong to a particular religion does not necessarily involves excluding alternative religious options, but acceptance and tolerance. In the Church history, Christian identity is formed not by excluding but including the Jewish and Roman traditions.

To conclude the discussion, there are several important points that can be observed. First, there is a gap between the lived reality of multiple religious belonging and the theological discourse on it. The various interpretations shows that there are various forms and experiences of this phenomenon. Therefore, what we need is a theology that can bridge this gap: theology that put emphasis more on the context (the "sign of time") than the text (the Bible and the Tradition). The inductive theology is more preferable in this context. The negative appreciation to the reality of multiple religious belonging certainly is caused by the lack of appreciation on the practical level.

Second, theological question on whether multiple religious belonging is possible or coherent from a dogmatic standpoint is still relevant concern. The growing number of the adherents of multiple religious belonging shows that there are needs for theological reflections and guidelines. Therefore, in the following part, I would like to discuss theological perspectives and its development in discussing the phenomenon of multiple religious belonging.

\section{DUPUIS' AND PIERIS' THEOLOGI- CAL RESPONSE}

Dupuis' doctrinal approach and Pieris' practical approach represent general theological observation to this phenomenon. Dupuis' theology maintains the uniqueness and universality of Jesus Christ and at the same time, offer an acceptable account for complementarity and convergence. Pieris begins his theology from his own experience as dual belonger, a Christian-Buddhist believer, and gives analysis of mutual enrichment between Buddhism and Christianity. 


\subsection{Jacques Dupuis and Trinitarian Chris- tology}

For Dupuis, the key point of doing theology in a pluralistic context is the deep experience and relationship with other religions in daily life, not with propositions and theories. Its point of departure is a practice of interreligious dialogue itself which helps for Christian interpretation of religious plurality. In other words, theology must be attentive to three hermeneutical process, namely text or the "given" faith, contemporary historical context and today's interpreter. ${ }^{24}$ Theology is not circular, but triangular: going from the "text" of the Christian memory in sacred scripture and sacred tradition (including the magisterium); to the "context" of the surrounding religio-cultural reality; to the "interpreter" which is the local church. Therefore, Dupuis brings the necessity of not judging deductively but theologizing inductively on the mater.

For Dupuis, the conditions for the possibility of multiple religious belonging can be based on doctrinal teaching, in Christological teaching. Dupuis' Christology is a Christology in a Trinitarian perspective which gives benefit in allowing us to "recognize the ongoing presence and activity of the Word of God and of the Spirit of God which make it possible to affirm a multiplicity of 'ways' and 'routes' toward human salvation." 25 The elements of truth and grace in other religions (AG 9) permit for "mutual complementarity" which is no other than a form of multiple religious belonging. Dupuis is able to affirm that multiple religious belonging is theologically necessary to Christian by revisiting teaching in Christology and Trinity. Dupuis goes deeper to offer a new model of multiple religious belonging called mutual complementarity.

Dupuis' Christology primarily aims to move beyond the traditional perspective in Christian theology of religions, called the fulfillment theology. The fulfilment theology is the extension of the fulfilment of the Old Covenant by Christ, to the fulfilment of other religions [religious pluralism] by Christ. ${ }^{26}$ Its core argument is that other religious traditions finds their fulfilment in Christianity, the locus of Jesus Christ. Other religions function as merely a human stepping stone which must eventually be fulfilled by Christianity. The fulfilment theology fails to create condition for interreligious relationship, since "Christianity would have nothing to receive but only to give, nothing to learn but only to teach."27
Dupuis argues for a mutual fulfilment or mutual enrichment between Christianity and other religions where each participant can be enriched and strengthened in their faith in God. ${ }^{28}$ To pursue this mutual fulfilment, Dupuis focus on a model of Trinitarian Christology which affirms "the elements of truth and grace" in other religions (AG 9) from which Christians can learn and be enriched. A Trinitarian Christology allows us to "recognize the ongoing presence and activity of the Word of God and of the Spirit of God in other religious traditions." ${ }^{29}$ Trinitarian approach focuses on the real distinction between the three persons of the Trinity, which means that one person of the Trinity cannot be reduced to or subordinated to another. If there is "real differentiation and plurality" between the Word of God in Jesus and the Spirit of God in other religions we can expect that the religions are going to have "different" and "new" things to tell Christians. ${ }^{30}$

Therefore, if non-Christian religions contain an "element of truth and grace" through the work of the Word and the Spirit and if they may be considered ways of salvation from which Christianity can and should benefit through dialogue, then there should be no theological objection against someone wishing to be a Christian and at the same time following some doctrinal teachings and religious practices of other religions, as long as these are not patently contradictory to Christian faith and moral. There is no theological objection to commit oneself to other religious traditions since the true aspects of the divine mystery can so stand out and be expressed in other traditions that even Christians can profit from contact and selfimmersion with them.

Dupuis argues for inclusive pluralism, a model that qualify the pluralistic approach with the inclusivist argument that Christ event as the unsurpassable reference point for God's dealing with humanity. It combines the universal God's saving will with the Christ event as the center of God's plan of salvation. Thus, God is revealed in, but not exhausted by, Christianity. Christians do not "possess a monopoly of truth." ${ }^{31}$ Inclusive pluralism leads to a relational convergence of religions which brings to mutual religious belonging.

Mutual interaction and enrichment on an equal footing is the inevitable reality for today and all the days to come. Different religions will contribute to each other in arriving at the content of the faith-experience of each. The different 'paths' are no more entirely different, isolated paths. Each path becomes a path by receiving insights from oth- 
er paths. Hence, the important point is the question of the uniqueness of one path as compared to other paths does not arise any more. Now, what we are interested in is the unique blending of two or more paths together for the emergence of the creatively new in each of the earlier paths. ${ }^{32}$

"Complementarity" is understood here not in the sense of the fulfillment theory according to which Christian truth 'brings to completion' in a one- sided process the fragmentary truths it finds sown outside. Rather, "complementarity" refers to "an exchange and a sharing of saving values or a dynamic interaction between Christianity and other religion. ${ }^{33}$ Dupuis is open to the possibility that some aspects of the divine mystery may be found stressed more vividly in other religions than in the Christian revelation. This therefore calls for interreligious dialogue in which participants may find their own faith stimulated and deepened by another's. For Dupuis, the process of dialogue is twoway. It is therefore possible that Christianity will find its own fulfillment through engagement with other traditions.By focusing on the mutual complementarity among religions, Dupuis opens up the possibility of adopting and living out other beliefs.

For Dupuis, the reality of multiple religious belonging can be a partial anticipation of the full recapitulation in Christ if all religions, which will only be disclosed at the end of time. ${ }^{34}$ Learning from the example of Henri Le Saux (Abhishiktanada) and the concept of Christ the Omega in Teilhard de Chardin, Dupuis concludes that the complementarity among religions is a teleological convergence that "the Church must never cease to grow toward her Fullness through encounter with other faiths." 35 Jesus Christ is the aims, the telos where all religions converge in Him, the fullest and deepest of God's self-communication to human beings.

Dupuis theology of religions centers its discussion on the Christological perspective that the humanity of Jesus Christ open to the unlimited work of the Word among religions. The critics of Dupuis is particularly on his a priori approach that bring the asymmetrical principle. For Dupuis, the inevitable consequence of his inclusivist perspective brings to the centrality of Christ as the "culminating point" for all religions. Therefore, the mutual relationship between Christianity and other religions is asymmetrical relationship. This means that the acknowledgement of additional and autonomous values of truth and grace in the other religions does not cancel out the unsurpassable tran- scendence of God's revelation and selfcommunication in the person and work of Jesus Christ. $^{36}$

\subsection{Aloysius Pieris}

Aloysius Pieris has acknowledged that his theology is inspired by two fundamental experience in Asia: his immersion in Buddhist studies and his exposure to Asia's massive poverty. ${ }^{37}$ For Pieris, Christianity will achieve real inculturation in Asia and become of Asia only by receiving a double baptism: at the "Jordan of Asian Religiosity" and on the "Calvary of Asian Poverty." The first baptism aims to enter the deep encounter with Asian religiosity and learn from it; meanwhile the second is the option of the Church toward the poor and oppressed people in Asia. These are the basic themes running throughout Pieris' theological works.

Some theologians dwelling on the subject such as Dupuis and Phan cite Pieris as a strong proponent, even as a pioneer and a model of the phenomenon of multiple religious belonging. In the context of Sri Lanka the question can be formulated as, can there be hyphenated religious identity such as Buddhist-Christian or HinduChristian? Pieris central arguments on multiple religious belonging can be seen in several points. First of all, Pieris offers a "core to core" dialogue, a "communicatio in sacris" in which Christianity's teachings will be enriched by Buddhism's teaching and vice versa. Secondly, Pieris also insists more strongly on the uniqueness of religious traditions, yet he aims for a "symbiosis" of mutual work and instruction, a symbiotic multiple belonging.

Pieris focuses to build the Church of Asia through "the Jordan baptism" to be truly inculturated with the Asian religions. It means that for Pieris, interreligious engagement is not much about intricate doctrines and histories, but it is about concrete relationship. One cannot build relation only through texts and theories, but it is possible only under the tutelage of an experienced guide, through a baptism in the Jordan, through tradition, rites and practices. On this level, Pieris calls the interreligious dialogue a communication in sacris, a religious communication through the total immersion in the religious practice and learning the language. However, the truly interreligious dialogue is when on penetrate the experiential level to the core level and build "core to core dialogue.” ${ }^{38}$ Pieris points out his immersion in Buddhism brought him to experience the necessity of a 
“core to core” dialogue between Christianity's agape and Buddhism's gnosis and vice versa. Love (agape) and wisdom (gnosis) are not mutually exclusive; rather agape and gnosis are each by itself inadequate to experience and express the Ultimate and therefore need each other. ${ }^{39}$

What must be borne in mind is that both gnosis and agape are necessary precisely because each in itself is adequate as a medium, not only for experiencing but also for expressing our intimate moments with the Ultimate Source of Liberation. They are, in other words, complementary idioms that need each other to mediate the selftranscending experience called "salvation." Any valid spirituality, Buddhist or Christian, as the history of each religion attests, does retain both poles of experience - namely the gnostic and the agapeic.

The dialogue with a Buddhist is not "from the core of Christianity" but "with the core of Buddhism." ${ }^{40}$ Thus, Pieris has provided a more compelling foundation for multiple religious belonging as he encourages the internalization of those two poles of which Christianity and Buddhism. Pieris affirms the multiplicity of cores not just the core of Christianity.

Pieris argues that each religion constitutes irreducible differences; therefore the goal in an interreligious encounter is neither syncretism nor synthesis but rather symbiosis. ${ }^{41}$ Pieris avoids the terms "syncretism," and "synthesis" in interreligious encounter because they tend to imply the violation of the unique individual identity of each tradition and because they gloss over differences. Syncretism, as Pieris identifies, is an unsystematic way of mixing of religions according to the preference or convenience of a person or group. Similarly, Pieris call synthesis, the creation of something altogether new out of two religions (or more) which destroys the uniqueness and identity of the original religions. The term "symbiosis" pointing out to a process of mutual supportive relations among religions without degrading one's religious traditions. Symbiosis is a movement in which members of different religions live and work together in basic human communities (and not just base Christian communities) especially in favor with the poor. ${ }^{42}$

Pieris, in contrast to the Dupuis' principle of asymmetry, offers symbiosis of religions that effects one's conversion to thespiritual heritage common to all religions (beatitudes) and also a conversion to the specificity (uniqueness) of one's own religion as dictated by other religionists in their common struggle for total liberation. The principle of asymmetry entails that other religious traditions find their fulfilment in the revelation of God in Jesus Christ. It holds together, at once, the mutual complementarity and asymmetry of God's revelation and salvation between the Christ-event and other divine manifestations to kind. ${ }^{43}$ However, Pieris, in contrast, in his approach of symbiosis of religions strictly maintains the irreducible, nonnegotiable and distinct "core" of each and every religion. Elisabeth Harris, recognizing Pieris' rootedness in his Christian faith, comments on Pieris' position concerning multiple and double religious belonging as follows:

Pieris in fact holds together the need for rootedness in one religious tradition and need for a plurality of insights into Truth. It is not a case of multiple belonging or dual belonging but a search for the Word that goes beyond structures, mediated through the language of one's own faith in encounter with that of others. It is this, perhaps, that the Sri Lankan experience can offer to this debate.

Pieris criticizes Dupuis' principle of "mutualasymmetrical-complementarity" since this position runs in the direction of "fulfillment theory" that asserts the elements of "truth and grace" (AG. 9) present in other religions finding their fullness in the mystery of Jesus Christ. For Pieris, the identities of all religions at the core level are "multiple" expressed in the two liberative languages, namely, "Wisdom" and "Love." Nevertheless, each religion legitimately uses its dominant idiomatic language, though not exclusively, to communicate their unique experience of liberation and their religious identity. Thus, Pieris does not see himself as multiple belongers. He seems uninterested indescribing himself as a ChristianBuddhist, rather, his goal is to encounter a deeper understanding and engage in a richer practice of Christianity. ${ }^{44}$

\section{THE GRASSROOTS STORIES OF MULTIPLE RELIGIOUS BELONG- ING}

Theological and academicals analyses presented above help us to enter into another level of discussion, the living experience of ordinary people. Different from theological approach, the focus in this part is in the living experiences, the "grassroots stories" of the ordinary people in Indonesia which certainly will deepen the discussion in this issue. There are two stories presented in 
this paper: the first story is an individual story of a female students who deeply engage in multiple religious belonging as Christian-Paraba believer; while the second is a story of Indonesian local beliefs which have been discriminated by the Indonesian government.

The first story is a story ofone of my students who belong or commit herself to two different beliefs: Catholic and PangudiRahayuningBawana, called Paraba, a local belief system in Central Java. Paraba, a Javanese mystical belief, was initiated by R. Soetisno in 1959 as the result of his spiritual journey seeking God's will. At the beginning, he actually did not want to begin a religious group or a sect; however, in order to get protection and appreciation from the government, on December $7^{\text {th }}$, 1959, Soetisno formally established Paraba in Semarang, Central Java. Nowadays, hundreds members of Paraba's believers have spread across Indonesia.The central teaching of Paraba is self-awareness that human person is God's creation; thus they must seek and direct their life to God Himself. For Paraba, the fullness of God-human relationship is attained through spiritual exercises, like meditation, fasting and praying. Paraba believes in God as Tri Purusha, namely God as the Ulimate Reality, God as the Ultimate Teacher and God as the Holy Spirit which point out the functional reality of God in God relationship with human beings. ${ }^{45}$

In the interview, she shared that she began his journey as Paraba's believer when she was in Junior High School at the age of 14. She was inspired by her father who was Paraba's believer; thus she decided to join their ritual and committed to their teachings. She certainly does not begin her multiple belonging in intellectual and theological level, but in her daily life together with her parents and neighbor who are the adherent of this belief. It is interesting to notice that her awareness to the theological "conflict," as it were, comes later when she begins her study in a Catholic school.

Another story I want to show perhaps the common situation in Indonesia regarding to the local religions and their believers, where they are practicing,at the same time, the local religious traditions and Indonesian "formal" religion. ${ }^{46}$ This multiple religious belonging is a solution or negotiation since the Indonesian government "force" all citizen to embrace formal religions. There are cases of the adherents of AratSabulungan in Mentawai, SundaWiwitan in Kuningan, Kaharingan in Palangkaraya and Marapu in Sumba who have to practice his/her local and formal religions alto- gether. ${ }^{47}$ Based on the government regulation UU Nomor 1/PNPS/1965, the adherents of the local beliefs had to choose "formal" religions. ${ }^{48}$ It is interesting to notice their opinions regarding this multiple religious belonging. Most of these dual belongers are able to integrate this duality. They share that their local beliefs are more like a culture, a way of life than a religion with structural entity which can be "mixed" with Christianity and Hinduism without any theological and practical problems. Other share that their local beliefs are their primary religion; meanwhile, the formal religion is the secondary that has to adjust and adopt the primary religion. They argue that their local beliefs are deeply rooted and determined their identity as a human person. Moreover, their local beliefs are more appropriate for their culture and situation than the "export" religions. Other also say that syncretism is the way out to deal with this duality. The blending and mixing of both teachings are inevitable consequence in the future. ${ }^{49}$

Analyzing the Grassroots Stories:The Multiple Religious Belonging's and Its Challenges

Rose Drew shows that there are two-fold challenges facing one as a multiple religious belonger. First, one must find satisfactory ways of integrating the Christian way of thinking and being and the local belief way of thinking and being. Second, one must, at the same time ensure that the unique character, insight and integrity of each tradition is preserved and what is special and attractive about each is not lost. ${ }^{50}$ In other words, the challenge is on how to integrate both traditions without losing the identity of each traditions.

The key point in my analysis in the first story is that Paraba is considered as a way of life, a Javanese mysticism which focuses more on the essence of the inner man (spirituality) than doctrinal teachings. Mysticism is different from monotheism. The logic of monotheism seems quite impossible to have multiple religious commitment, particularly in its "oneness" paradigm: "Their monotheistic (Abrahamic faiths) character encourages all of them to call for the primary commitment of their members which means demands total commitment, a singular identity. ${ }^{51}$ Phanalso points out how multiple religious belonging creates a problem when it meets with monotheist religion:

Multiple religious belonging emerges as a problem only in religions that demand an absolute and exclusive commitment on the part of their adherents. This seems to be the case with the "Religions of the Book" namely Ju- 
dasim, Christianity and Islam. Not so with most other religions, particularly in Asia, in Hinduism, Buddhism, Taoism and other local beliefs. ${ }^{52}$

In my interview, she shares that the relationship between Paraba and Christianity is not a competitive relationship but mutual complementarity: "Paraba is the inner essence; meanwhile, Christianity is the outer entity. Both are importance and complementarity each other." ${ }^{, 53}$ She experiences that Paraba enrich Christian faith in many ways. First, Paraba enrich her Christian spirituality through the practice of meditation (sujud and semedi) and fasting. Second, Paraba deepens her understanding on Christian's teachings. For example, the law of love in Christianity is an abstract commandment. However, Paraba makes it clearer by giving concrete ways in loving others. Meanwhile, Christianity contributes to the adherents of Paraba a concept of personal God, Jesus Christ who is immanent and transcendent. She honestly says that Christianity's strong monotheism centered on the oneness of God, Jesus Christ has helped her to find God as an immanent figure who is very close and real. She shares that committing to Christianity and Paraba have helped her to be more faithful and mature as a person.

In the second case, in the multiple religious belonging case of Arat Sabulungan believers in Mentawai, Christianity is considered as the inclusive religion which can embrace and tolerate the local beliefs more than other formal religions. Therefore, they prefer Christianity as the secondary religion. However, different from the previous case, believers of AratSabungan and Marapu embrace Christianity due to the government policy. ${ }^{54}$ They do not have freedom to choose. In the case of postcolonial studies, their multiple belonging is a survival strategy, a form of resistance against colonialism's project of domination and effacement. ${ }^{55}$ Their experience shows another model of multiple religious belonging called the "hybrid," a model for multiple religious belonging where the identity of these hybrids is both double and partial. Hybrid identity is double because it affirms multiple realities; it is partial because it never completely at home in any of them. ${ }^{56}$ They never really synthesize or make agreement to bridge both religious traditions. They do not resolve the tensions between traditions even though they engage to both tradition in their daily life. Thus, for AratSabungan and Marapu believers, their multiple belonging does not reach a significant mutual complementarity as it happens in the first case.
Multiple Religious Belonging is Not "Spiritual Marketplace". A critical perspective considers that this reality as symptoms of a postmodern way of thinking, particularly in a New Age religiosity characterized by individual autonomy and rejection of all truth-claims of religions; a shallow consumer culture through derisive metaphors of shopping in the spiritual marketplace. ${ }^{57}$ Multi religious identities are sometimes seen as, or associated with, a superficial "pick and mix" approach to religion, to what Peter Phancallsa "postmodernformof syncretism in which a person looks upon various religions as a supermarket "from which one selects what ever one likes, "without regard to...truth value sand mutual compatibilities." 58

However, from the two cases, I can conclude that multiple religious belonging is not a superficial attitude as a symptom of New Age religiosity characterized by "believing without belonging." In fact, there are several points that show a deep theological commitment exceeding the negative judgment given by some theologians. In this analysis, I would like to focus on the first story, Christian-Paraba believer.

First, both cases demonstrates that it is possible to be immersed in two traditions and to take the demands of both traditions seriously without reservation. The fact that they have committed to both traditions for many years certainly provides evidence that they do not simply superficially pick and mix without commitments.

Second, multiple religious belonging is not duality in faith. Based on my interview in the first story, she does not think that she has dual faith combined together, but she considers it as one faith inspired, transformed and deepened by the other. She does not see it as duality in religions, an "either/or" way of thinking. As Kwok Pui-Lan views that multiple religious belonging begins by choosing or rooting in a single tradition, while seeking its constant transformation by the inspiration of others. ${ }^{59}$ In the same way, Schreiter views that multiple religious belonging does not primarily mean that people "belong" to multiple religions in the standard sense of adding or simply combining several affiliations, but it means that people of faith construct their sense of religious belonging using beliefs, expressions and practices of various religious traditions, without even bothering whether they would like to be recognized as "belonging" to those traditions by the traditions themselves. The primary identity is her local beliefs (Paraba) as she were born on that religious traditions, while their secondary identity is Christian. 
Following Claude Geffre argument, there is inextricable union between religion and culture, especially in Asia and hence on the person's identity as comprising both religions and culture. ${ }^{60}$ Her primary identity as a believer of Paraba is constantly transformed and inspired by her Christian tradition. Meanwhile, for AratSabungan and Marapu believers, Christianity plays a function as other identity which affirms their primary identity. In other words, the mingling of multiple traditions for Marapu and AratSabungan can be a means of affirming their marginalized identity as a local belief. Christian's identity helps them to be recognized and affirmed as legal religions.

Third, there is a possibility for multiple religious belonging to arriveata coherent world- view and self-understanding informed by both traditions. In the first case, the common element is the concept of God as Tri Purusha which, according to her, is very close to the concept of the Trinity. Tri Purusha believes that God has three functions: God as the Ultimate Reality, Go as the True Teacher and God as the Holy Spirit. These three God's manifestation is easily to be understood as the Christian's Trinity.

What is the Contributions of Multiple Religious Belonging to Christianity? The Church through the document of Pontifical Council for Culture entitled “ Towards a Pastoral Approach to Culture" stresses the importance of dialogue with culture, for "faith that does not become culture is a faith not fully accepted, not entirely thought out, not faithfully lived." ${ }^{\circ 1}$ The Church acknowledges that human person are rooted in the culture. However, the Church warns that human person are not totally determined by culture:

It must also be admitted that man is not exhaustively defined by that same culture. Moreover, the very progress of cultures demonstrates that there is something in man which transcends those cultures. This 'something' is precisely human nature: this nature is itself the measure of culture and the condition of ensuring that man does not become prisoner of any of his cultures, but asserts his personal dignity by living in accordance with with the profound truth of his being.

The Church open to dialogue with the culture even though she also has the obligation to evangelize the culture and inculturate Christian faith into culture. ${ }^{62}$

Multiple religious belonging gives positive contributions to Christianity. First, multiple reli- gious belonging deepens the spiritual aspect of Christian faith. The values of meditation and fasting helps Christians to be more aware of the spiritual aspect in their faith. Christianity is too focus on the hierarchical, liturgical and doctrinal aspects of their faith and set aside the spiritual depth of our inner being. Many people today are seeking a new who lanes and that is why so many people are turning to meditation, in need of "a time and place for quietness and spiritual nourishment." 63

Second, multiple religious belonging encourages Christian to engage in interreligious dialogue. Raimundo Panikkar suggests that interreligious dialogue presupposes intra-religious dialogue, a personal encounter with other in the depth of the heart by entering emphatically into the experience of the other, or to understand from within. ${ }^{64}$ Therefore, multiple religious belonging is a form of intra-religious dialogue which brings to ideal dialogue, a dialogue that begins not with theological conception, but with empathy and openness by deeply entering other way of thinking.

Third, multiple religious belonging bring to the mutual transformation. The shock of the encounter with other religious traditions will often raise question and force Christians to revise gratuitous assumptions, and destroy deep-rooted prejudice of overthrow certain narrow conception. ${ }^{65}$ It brings toward a deeper conversion of each to God. The same God speaks in the heart of both partners; the same Spirit is at work at both. John Cobb contends that if Christianity is a living movement, it must be ready to learn even if threatens my present belief.

\section{CONCLUSION}

This paper begins with a simple statement that the phenomenon of multiple religious belonging brings us to the future of theology, a theology that multi-religious and multi-faith, a theology that Christians-along with their brothers and sisters in other traditions- come to see themselves as heirs to the whole religious history of human kind and to embrace, within the context of dialogue, the challenge of working out how the insights of the various traditions of the world relate to each other. However, this future theology is not a set of theological conception formulated from Biblical or doctrinal teachings, but it is a theological methodology as a way of doing theology characterized by openness, empathy and love among religions. Therefore, by focusing on the methodology, we choose to focus on the living experiences of 
people so that we can learn from the other, being challenged and transformed by the other uniqueness. This requires that theologians learn to be "systematic without being systemic" and while holding on to their religious identity, they must engage in a "theology of dialogue," not merely build a "theology for dialogue." 66 The model that needs to be developed in the multi religious context

...is not that of mutual assimilation through a reduction of faith-content but that of interpenetration and cross-fertilization of the various traditions in their diversities; not a leveling of religious identities but a dialogical openness and mutual enrichment through conversation. $^{67}$

This paper also begins with the premise that multiple religious belonging is possible in the context of religious pluralism. However, as we move to a deeper discussion, is it also desirable as the way people living their religions? Cornille argues that multiple religious belonging certainly can give benefits in their religious life. However, this does not necessarily mean that it should or could be advocated as an ideal. Cornille is partly true that committing seriously and deeply into two or more religions would not be easy choice. But, if we reflect on the living experience of ordinary people, committing to two or more religious traditions is considered as way of life, as the way to deepen personal faith and to build the community. In this ordinary experience, theology renews and begins its reflection.

\section{Alexander Hendra Dwi Asmara}

Program Studi Ilmu Pendidikan Agama Katolik, Fakultas IKIP, Universitas Sanata Dharma Yogyakarta, Email: hendrasj@gmail.com

\section{ENDNOTE}

1 Jose Maria Vigil, ed., Toward a Planetary Theology: Along the Many Paths of God (Montreal, Canada: Dunamis Publishers, 2010), 8.

2 Wilfred Cantwell Smith, Towards a World Theology (Maryknoll, NY: Orbis, 1986), 112.

3 Devaka Premawardhana, "The Unremarkable Hybrid: Aloysius Pieris and the Redundancy of Multiple Religious Belonging," in Journal of Ecumenical Studies, 46:1, Winter 2011, 53.

4 Michelle Voss Robert, "Religious Belonging and the Multiple," in Journal of Feminist Studies in Religion, Vol.26 (Spring 2010), 47 and 60-61.

5 Van Bragt, Jan, "Multiple Religious Belonging of the Japanese People,” in Catherine Cornille, (ed.),
Many Mansions? Multiple Religious Belonging and Christian Identity, (Maryknoll: Orbis 2003), 7-19.

6 Ibid., Devaka, 49.

Ibid, Voss Roberts, 44.

8 Catherine Cornille, "Double Religious Belonging: Aspects and Questions,” in Buddhist-Christian Studies, Vol. 23 (2003), 43-49.

9 Tinu Ruparell, "Interreligious Dialogue and Interstitial Theology ,” in Catherine Cornille, ed., The Willey-Blackwell Companion to Interreligious Dialogue (NY: John Wiley \& Sons. Ltd. Published, 2013), 118.

10 Robert J. Schereiter, The New Catholicity: Theology between the Global and the Local (Maryknoll, N.Y.: Orbis Books, 1997), 73-75.

11 Ibid.,Cornille, "Double Religious Belonging: Aspects and Questions," 45.

12 Ibid, 48.

13 RaimundoPanikkar, The Intrareligious Dialogue (New York: Paulist Press, 1978), 2

14 Peter C. Phan, "Multiple Religious Belonging: Opportunities and Challenges for Theology and Church,” in Being Religious Interreligiously (Mryknoll, N.Y.: Orbis Books), 2004, 61.

15 CatherineCornille, "Introduction: The Dynamic of Multiple Belonging,” Many Mansions? Multiple Religious Belonging and Christian Identity (Maryknoll, NY: Orbis Books, 2003), 3.

16 The core question in discussing multiple religious belonging and its challenges to Christian identity has been elaborated deeply by Peter C. Phan, Robert C. Schreiter, Jacques Dupuis, John Cobb, Jr, Catherine Cornille, Pieris and many other theologians.

17 Forms of resistance, especially "because power plays such a strong role in cultural encounter, and because that encounter is often intrusive, unequal, and violent, the reaction to the encounter isnot infrequently resistance. A second set of identity formations might be called hybridities (explained above). A third formation of religious identity might be called hierarchical. By this is meant that church leadership or its intellectual elite try to move the cultural and religious mixing in a certain direction. (Robert J. Schereiter, The New Catholicity: Theology between the Global and the Local (Maryknoll, N.Y.: Orbis Books, 1997), 73-75.

18 Ibid, 74.

19 For a deeper discussion on syncretism, see TinuRuparell, "Interreligious Dialogue and Interstitial Theology," in Catherine Cornille, ed., The WilleyBlackwell Companion to Interreligious Dialogue (NY: John Wiley\& Sons. Ltd. Published, 2013) and Robert J. Schreiter, Constructing Local Theologies (Maryknoll, NY: Orbis Books, 1985), chapter 5 and 7.

20 Ibid.,Schereiter, The New Catholicity, 75.

21 Ibid.,Phan, "Multiple Religious Belonging," 69.

22 Ibid.,Schreiter, The New Catholicity, 73-75.

23 Kwok Pui-Lan,’Interfaith Encounter," in Arthur Holder, ed., the Blackwell Companion to Christian 
Spirituality (USA: Blackwell Publishing, 2005), 534.

24 Jacques Dupuis, Toward a Christian Theology of Religious Pluralism, (NY: Maryknoll, 1997), 15-20.

25 Ibid, 164

26 Adam Sparks, "The Fulfillment Theology of Jean Danielou, KarlRahner and Jacques Dupuis,” New Blackfriars, Vol.89, Issue 1024, (November 2008), 634.

27 Dupuis, "Christianity and Religions: Complementarity and Convergence," in Cornille, ed., Many Mansions? Multiple Religious Belonging and Christian Identity (Maryknoll, NY: Orbis Books, 2002), 65.

28 Dupuis, Christianity and the Religions:From Confrontation to Dialogue (NY: Maryknoll, 2003), 25

29 Ibid, 144

30 Ibid, 206, 197-198.

31 Dupuis, Christianity and the Religions: From Confrontation to Dialogue (NY: Maryknoll, 2003),382.

32 Ibid, 345.

33 Dupuis, Christianity and the Religions: From Confrontation to Dialogue, 257

34 Kwok Pui-Lan, “Interfaith Encounter,” 542.

35 Voss, "Religious Belonging and the Multiple," 48.

36 Dupuis, Christianity and the Religions: From Confrontation to Dialogue, 256.

37 See A. Pieris, "Two Encounters in My Theological Journey," in Frontiers in Asian Christian Theology: Emerging Trends, ed. R. S. Sugirtharajah (Maryknoll, NY: Orbis Books, 1994), 141-146.

38 FrederixGlorieux, "Does Christ Have an Asian Face? An Analysis of Aloysius Pieris' Theology of Religions,” in Louvain Studies 30 (2005), 336.

39 Peter C. Phan, "Jacques Dupuis and Asian Theologies of Religious Pluralism,” 77-78.

40 Ibid.,Devaka, 84.

41 Phan, "Multiple Religious Belonging: Opportunities and Challenges for Theology and Church," 76.

42 Ibid, 77.

43 Dupuis, Christianity and the Religions:From Confrontation to Dialogue,136 and 257

44 Ibid.,Devaka, 87.

45 Purwo Adi Prasetyo dan Waskito, Ajaran Organisasi Penghayat Kepercayaan terhadap Tuhan Yang Maha Esa Pangudi Rahayuning Bawana (Jakarta: Depdikbud, 1996).

46 In this second grassroots story, I primarily refer to Tempo Magazine, "Yang Lokal, Yang Tersisih,” 27 October - 2 November 2014, pp. 57-70.

47 In Indonesia, this situation is very common when the government obligates the Indonesian citizens to choose one formal religion. Many Indonesian who are the adherents of the local religions are forced to abandon their belief and they compromise it by publicly confessing the official religion, but privately practicing their local religion. (See Tempo Magazine, "Yang Lokal, Yang Tersisih,” 27 October - 2 November 2014, pp. 57-70).
48 Therefore, Kaharingan in West Java and Aluk Todolo in Tana Toraja believers choose to embrace Hinduism, for it has similar teachings. Others local believers chose Christianity as the primary religion,

like Arat Sabulungan in Mentawai and Marapu in Sumba, for Christianity shows more respect and tolerance to their beliefs.

49 See. Tempo Magazine, "Yang Lokal, Yang Tersisih,” 27 October - 2 November 2014, pp. 57-70.

50 Rose Drew, "Christian Self-Understanding and the Question of Dual Belonging," in Current Dialogue(Special Issue) December, (2011), 62.

51 Voss, "Religious Belonging and the Multiple," 53.

52 Phan, "Multiple Religious Belonging: Opportunities and Challenges for Theology and Church," 59.

53 In this part, I find out the similarity between Dupuis' theological ideas on mutual complementarity with her experience as Christian-Paraba believer.

54 Some of Marapu's believers share that they have to embrace Christianity or Islam in order to be acknowledged as the legal citizens. Otherwise, they would get any services from the local government.

55 Ibid., Voss Roberts, 44.

56 Ibid., 51.

57 Catherine Cornille, "Double Religious Belonging: Aspects and Questions,”, 43-49.

58 Ibid., Peter C. Phan, Being Religious Interreligiously, 62 .

59 Ibid.,Kwok Pui-Lan,” Interfaith Encounter,” 534.

60 Geffre reminds us the fact that in some culture, one's identity is deeply influenced and determined by his/her culture. He points out a forceful reminder: "What would the Indian identity consist of outside of Hinduism? What would comprise the Chinese identity without the complex religious mixture of Taoism, Confucianism and Buddhism?” Amaladoss shares the similar argument that for him, Hinduism is part of his identity, as the religion of his ancestor. Therefore, in Javanese culture, particularly in the remote area, people are inherited their Javanese beliefs as their primary identity. In other places in Indonesia certainly experience the same thing.

61 Towards a Pastoral Approach to Culture, from http://www.vatican.va/roman_curia/pontifical_coun cils/cultr/documents/rc_pc_pccultr_doc_03061999_ pastoral_en.html

62 The document defines culture as particular way in which persons and peoples cultivate their relationship with nature and their brothers and sisters, with themselves and with God, so as to attain a fully human existence (Cf. Gaudium et Spes, 53)

63 Ibid., Drew, "Christian Self-Understanding and the Question of Dual Belonging,” 65.

64 Paul F. Knitter, Introducing Theologies of Religions (Maryknoll, NY: Orbis Books, 2003), 128-130.

65 Ibid., Dupuis, Christianity and the Religions, 234.

66 Ibid., 84.

67 Dupuis, Toward a Christian Theology of Religious Pluralism (NY: Maryknoll, 1997), 5. 


\section{BIBLIOGRAPHY}

\section{Books and Journals}

ed. Many Mansions? Multiple Religious Belonging and Christian Identity,Maryknoll, NY: Orbis, 2003. , 2001, Christianity and the Religions: From Confrontation to Dialogue. Orbis Books, NY.

2003, "Christianity and Religions: Complementarity and Convergence."In Many Mansions? Multiple Religious Belonging and Christian Identity, edited by Catherine Cornille, 61-75. Maryknoll, Orbis, NY.

Cornille, Catherine. "Double Religious Belonging: Aspects and Questions.” Buddhist-Christian Studies, Vol. 23 (2003): 43-49.

Drew, Rose. "Christian Self-Understanding and the Question of Dual Belonging." Current

Dialogue (Special Issue) December, 2011: 60-69.

Dupuis,Jacques, 1997, Toward a Christian Theology of Religious Pluralism. India: Gujarath Sahitya Prakash.

Glorieux, Frederix.,2005, "Does Christ Have an Asian Face? An Analysis of Aloysius Pieris' Theology of Religions.” Louvain Studies 30: 336-348.

Panikkar, Raimundo, 1978,The Intrareligious Dialogue. Paulist Press, NY.

Phan, Peter C, 2004 "Multiple Religious Belonging: Opportunities and Challenges for Theology and Church.” In Being Religious Interreligiously, Peter C. Phan, 60-81. Maryknoll, Orbis Books, NY.

Pieris, Aloysius,1994, "Two Encounters in My Theological Journey.” In Frontiers in Asian Christian Theology: Emerging Trends, edited by R. S. Sugirtharajah, 141-146. Maryknoll, Orbis Books, N.Y.

Pui-Lan, Kwok. "Interfaith Encounter." In the Blackwell Companion to Christian Spirituality, edited by Arthur Holder, 547-537. Blackwell Publishing, USA:, 2005.
Prasetyo, Purwo Adi dan Waskito, 1996, Ajaran Organisasi Penghayat Kepercayaan terhadap Tuhan Yang Maha Esa Pangudi Rahayuning Bawana. Depdikbud,Jakarta.

Premawardhana, Devaka. "The Unremarkable Hybrid: Aloysius Pieris and the Redundancy of Multiple Religious Belonging.” Journal of Ecumenical Studies, 46:1(Winter 2011): 76-101.

Robert, Michelle Voss. "Religious Belonging and the Multiple.” Journal of Feminist Studies in Religion, Vol.26 (Spring 2010): 43-62.

Ruparell, Tinu. "Interreligious Dialogue and Interstitial Theology.”, 2013, In The WilleyBlackwell Companion to Interreligious Dialogue, edited by Catherine Cornille, 117132. John Wiley \& Sons. Ltd. Published, NY.

Schereiter, Robert J. 1997, The New Catholicity: Theology between the Global and the Local. Maryknoll, Orbis Books, NY.

Sparks,Adam, 2008, "The Fulfilment Theology of Jean Danielou, Karl Rahner and Jacques Dupuis,” New Blackfriars, Vol.89, Issue 1024: 633-656.

Smith, Wilfred,1986,Cantwell.Towards a World Theology. Maryknoll, Orbis Books, NY.

Tempo Magazine, "Yang Lokal, Yang Tersisih," 27 October - 2 November 2014: 57-70.

Van Bragt, Jan, 2003, "Multiple Religious Belonging of the Japanese People.” In Many Mansions? Multiple Religious Belonging and Christian Identity, edited by Catherine Cornille, 7-19, Orbis, Maryknoll, NY.

Vigil, Jose Maria, ed., 2010, Toward a Planetary Theology: Along the Many Paths of God (Montreal, Canada: Dunamis Publishers.

Knitter, Paul F., 2003, Theologies of Religions: Introduction.Maryknoll, Orbis Book, NY.

\section{Internet}

Towards a Pastoral Approach to Culture, from http://www.vatican.va/roman_curia/pontifical_cou ncils/cultr/documents/ 